\title{
Evaluation of Science Learning Supervision on Secondary Schools
}

\author{
Astin Lukum ${ }^{1, *}$ \\ ${ }^{1}$ Dept. of Chemistry Education, Gorontalo State University, Indonesia \\ *Correspondence: Jl. Jenderal Sudirman No. 6 Kota Gorontalo 96128, Indonesia \\ Tel: 62-813-5645-1963Ｅ-mail: astinlukum@ymail.com
}

Received: September 5, 2013 Accepted: September 23, 2013 Published: October 22, 2013

doi:10.5296/ije.v5i4.4240ＵRL: http://dx.doi.org/10.5296/ije.v5i4.4240

\begin{abstract}
This research aims were (1) the support of the policy, (2) the resources, and (3) the implementation of science learning supervision, (4) the performance of secondary science teachers in Gorontalo City. The conclusions that (1) the supervision was based on laws of national regulations, (2) Teachers perception based on their experiences, supervisors and school principals focused on the schools and classroom visit supervision, their characteristics were in accordance with the National Standard, and potentially to be developed. The resources has met the Minimum Service Standard (MSS), (3) the implementation of science supervision has not met the MSS. and (4) teachers performance; best $16 \%$, good $43 \%$ and fair 5\% and remaining (36\%) did not have the willingness to be supervised.
\end{abstract}

Keywords: evaluation; science learning; supervision; CIPP models; secondary school 


\section{Introduction}

The quality of the supervision implementation depends on the competences and the professionalism of the supervisor. The supervision of science learning in the school system in Indonesia is still restricted on the physical and administration aspects. The lack of attention on the implementation of learning supervision is shown by the lack, or none in the certain area, of supervision of subject with the qualified supervisor. The supervisors of the science learning in the Province of Gorontalo have not competencies enough on that field. For the detail, the Regency of Gorontalo has 3 science learning supervisors for 131 secondary school, the city of Gorontalo has 3 supervisors for 21 secondary school, Boalemo Regency has 1 supervisor for 40 secondary school and Pohuwato Regency has 1 supervisor for 38 secondary school. Unfortunately, not all of them have the background of science, but the background is still the cluster of science (Biology, Physics, and Chemistry). In fact, the quality of science learning really depended on the professionalism of the science teachers. The teachers need the helps to increase their professionalism. One of them is the learning supervision.

The trend of the science learning supervision is focused on only one of the supervision techniques, i.e. classroom visit, to observe the learning has meet the lesson plan or not, and without helping to the teachers difficulties and problems. There is also supervisor focuses on the administration aspect only, by checking the list of presence of the teachers. Normally, the supervisor comes to the school twice in a semester (at the beginning of semester and at the examination). In fact, the supervisor should be the partner of teacher to develop the quality of science learning in the classroom.

The supervision of the science learning should be directed to the creation of the professional science teacher who has the capability to develop the learning process. So, the supervision is the efforts to help the teachers. Therefore, the supervisor needs to keep learning, read the updated information, develops the creative ideas in the learning.

The science supervision program is closely related to the support of wisdom, resources which could support the implementation of supervision. The product of implementation is the good performance of science teacher of secondary school in Gorontalo. It is expected that the product also give the impact to the learning results of the students.

The learning supervision is the research on program evaluation. This research employed the qualitative and quantitative approaches. Some of the models were explained by Stufflebeam including evaluation of Context, Input, Process and Product (CIPP).

The context which is related to the science supervision program in Gorontalo is the support on the policies, including policy of learning supervision and comprehension of the policy maker. The inputs are the resources of the supervision including the comprehension of the science teachers, supervisors, and headmasters, characteristics of supervisor and science teachers as well as facilities and infrastructures. The processes are the implementation of the science learning supervision by the supervisors and headmasters, the perception of science teachers on the supervision as well as the efforts of the supervisors and headmasters in 
developing their competences. The product is the quality of the secondary school science teachers in Gorontalo.

According to the previous explanations, the supervision program of science subject in Gorontalo is one part of the quality management activities in educational unit. This assumption is based on that supervision on science subject is a need of the teachers on the unit. Therefore, the supervision should be a priority in the development of education in Indonesia.

The supervision of science is a program that should be monitored from the related parties. There is an indication that the implementation of the supervision in the real life does not occur as it should be. There are some problems such as the readiness of supervisors, headmasters, the teachers as well as facilities and infrastructures. Therefore, intensive research on the evaluation of supervision of science in secondary school in Gorontalo should be conducted in order to see and monitor the implementation of the supervision.

This research explored several problems they were: (1) how was the policy support on the supervision of science in secondary school in Gorontalo city?; (2) how was the resources of the supervision of science in secondary school in Gorontalo city?; (3) how was the implementation of the supervision of science in secondary school in Gorontalo city?; (4) how was the performance of science teachers in secondary school in Gorontalo city?.

\section{Theoretical Framework}

\subsection{Evaluation of Program}

Muliati (2005) stated several evaluations in the field of knowledge. One of them was the evaluation of program which was commonly employed in the study in the field of education. This evaluation was significantly developed since the era of Ralph Tyler, Scriven, John B., Owen, Lee Cronbach, Daniel Stufflebeam, Marvin Alkin, Malcolm Provus, R. Brinkerhoff, etc. Studies of the evaluation implied on the development of several evaluation models. In principle, the models had the same aims, such as providing the information to make decision for the policy maker.

Gronlund (as cited in Roswati, 2008) stated that "the evaluation of program was the activity to collect either quantitative or qualitative data and information which were used by the policy maker to consider whether the program should be developed, stopped or continued" (p.23).

Based on the previous explanation, the evaluation of program could be defined as the evaluation on the implementation of the program was quantitatively and qualitatively employed to consider whether the program should be developed, stopped or continued.

\subsection{Supervision of the Science Learning}

Supervision of the science learning was aimed to fix the learning situation, thus the students could know the process, product and application of science in technology. In addition, the 
student could have the responsibility either to themselves or the society (Harbeck as cited in Paramata, 2001). Furthermore, Eiss (as cited in Paramata, 2001) as well National Science Teacher Association (as cited in Paramata, 2001) stated that "the efforts to fix the learning should be comprehensively, continuously conducted with the skills”(p.81)

The subject of science could be considered in the views of: (1) empiric, systematic and logic scientific process; (2) tentative scientific product; (3) scientific behavior such as the curiosity, open-minded, responsible, sensitive to the environment, creative, innovative and cooperative; (4) application on the technology, values of scientific knowledge and the existence of human being as the users of technology.

Science was the knowledge regarding to the object and phenomenon which has been verified, particularly on two aspects. There were science as the process known as the scientific method and product (body of knowledge). Besides, science had the values of sciences. Science could be considered as a process initialized from the evaluation of the natural phenomenon with the methodology and finally it produced the scientific products such as fact, concept, principle, law or theory. By employing the scientific process, the scientific behavior of each people who deal with science could be conducted. Additionally, through the process skills to observe, explain, think and make decision could be developed. Besides, science could increase the sense of love and belonging of the almighty of Allah SWT, and to systematically and rationally solve the problem (Paramata, 2001).

Based on Aderusliana (2009), science was the effective mode to develop the skill of thought development in order to have the scientific behavior in the era of technology. In the implementation, the control of supervision should be also considered.

Supervision program of science which was developed should give the contribution on the professional development of teacher. Naturally, supervision has been carried out by the teacher on the learning process. By doing the supervision, the teacher got the practical experiences on the learning. The experiences were the ways to improve the quality of the teacher in the class. The concept of education of science was universal. The applied educational depended on the resources including the political system and culture.

The application of supervision model of educational system was dynamic as it adapted the development of the system of education. Sergiovanni (1987) said that the aims of supervision were to: (1) help the teacher to develop the professional skill in the academic comprehension, life on class, the skill to use the skill by using particular techniques; (2) monitor the learning process in the school (such thing could be achieved on the visit to the class, conversation with the teacher or personal colleague and student and (3) support the teacher to apply the assessment techniques and find the self-development and commitment in finishing the tasks.

A supervisor should understand the existence of the teacher, including the commitment and the abstraction ability of the teacher. Glickman (as cited in Masaong, 2010), categorized the level of teacher commitment into high and low. According to the commitment and the level of abstract, the supervisor could make the category of teacher from low into high by employing four quadrants of behavior (Figure 1.). 


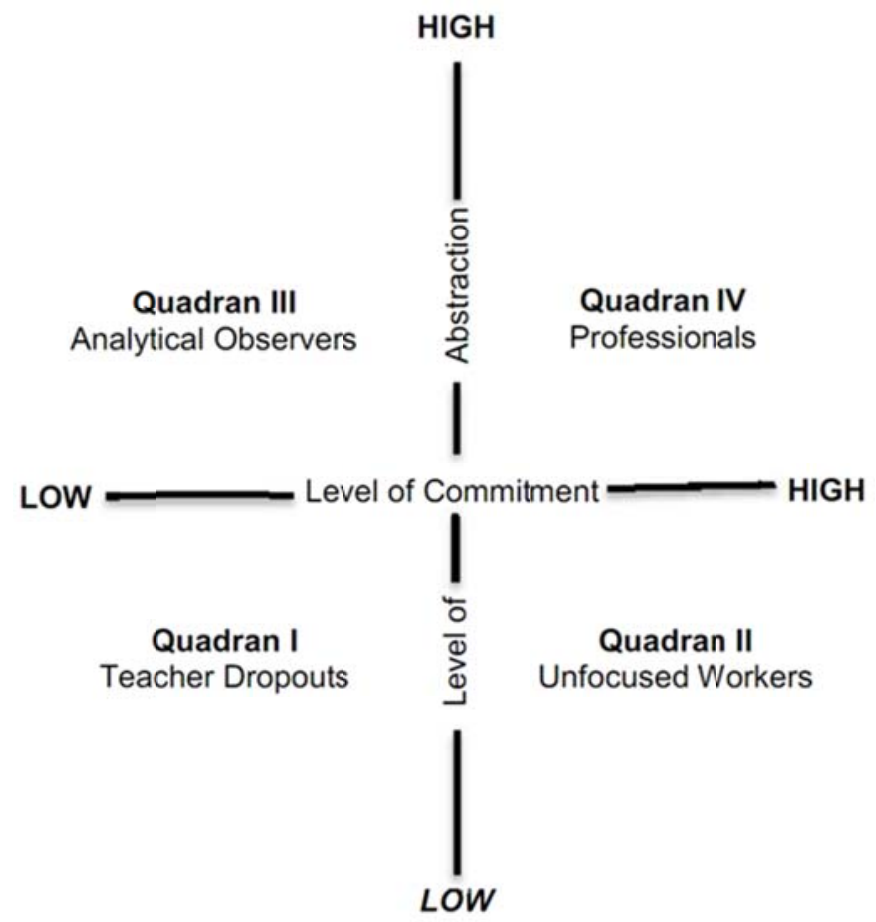

Figure 1: Category of teacher behavior Glickman (as cited in Masaong, 2010) (P. 51)

As depicted on Figure 1, the type and category of teacher could be known and it helped the supervisor to choose the right approach or supervision orientation. For instance, (1) the drop-out teacher with the low commitment level and level of abstraction (to deal with such teacher, supervisor might use the directive method); (2) the unfocused teacher with high commitment but with low thinking level (to deal with such teacher, supervisor might use the collaborative method); (3) the analytical observer teacher with high level of abstraction but low commitment level (to deal with such teacher, supervisor might use the collaborative method with the emphasize on the negotiation; (4) professional teacher with the high commitment and level of abstraction (to deal with such teacher, supervisor might use the non-directive method).

According to the previous explanation, the supervision on the subject of science could be defined as the professional help to the science teacher which should be done by the supervisor and headmaster with the basis of continuous and sustainable partnership and supervision to achieve the success on the learning. It could be indicated by the policy, resource, implementation, result and the performance of the science teacher.

\subsection{CIPP Model Evaluation}

The model of CIPP was developed by Stufflebeam in Ohio State University in 1986. The positive of this model was on the evaluation related to the decision maker, planning and operational of the program. In addition, the model gave the comprehensive evaluation format on each evaluation steps of context, input, process and product (Van Fuddin Batavia, 2008).

Evaluation of context provided the initial basis, including direction, aim and operational procedure of the implementation of the program that became the main support in the 
achievement of the program. The supervision program was one of educational managements that had basis of hierarchy policy from the center to the region. The basis of policy was the Decree No. 20, 2003 about the National Educational System, which was explained on various rule and decision of either central or region government. According to the previous explanation, the context of this research was the policy support on the supervision of science subject in secondary school in Gorontalo city.

In order to achieve the goals of the program, the resources were required to implement the policies as explained on the evaluation of context. Therefore, the resources were the part of input evaluations.

McLemore (2009) stated that the input evaluation determined the available resources, alternative strategies and the following plans to fulfill the need of procedure program design. Evaluation of input was related to the utilization of the available resources which were used to achieve the designed program. The inputs of the supervision of science on this research were human resources, including supervisor, headmaster, science teacher, as well as facility and infrastructure which could support the supervision.

The implementation of the regulated program in various policies which was supported by the available resources was a process to achieve the goal. Therefore, implementation of the program was also called as the step of process. To know whether the success of the process, the evaluation of the process should be conducted.

Johnson (2011) stated that the evaluation of process included the investigation about the conducted program, the monitoring and audit of the program and the identification of the limitation on the procedural design or in the implementation of the program.

The evaluation of the process provided information about the implementation of program and data for the decision on the implementation program. In addition, it could also determine how to use the resources to achieve the goals. In this research, the focus of evaluation was the implementation of the supervision science learning in secondary school in Gorontalo which was based on the regulation about the supervision by optimizing the available resources such as supervisor, headmaster and teacher.

The success of the program could be seen from the product. If the program meets the requirements as expected on the designed policies and is supported by the available resources for the implementation, the program will be considered to be successful. Thus, the evaluation of product was the important part in the evaluation of program, even it was the grand conclusion.

Evaluation of product was the assessment to see the success of the program in achieving the goals. In this step, the evaluator could determine or give recommendation to evaluant whether the program could be continued, developed, modified or stopped (Pratama, 2010).

Based on the previous explanation, the evaluation of the product was employed to measure the achievement in the end of the program. In this research, the focus of evaluation was the performance of the science teacher in applying the learning in the class. The implementation 
of the learning in the class was closely related to the success of the implementation of the supervision of the science learning by the supervisor or headmaster. It is also supported by the commitment of teacher as well as the available facility and infrastructure.

\subsection{Criteria of Evaluation}

Criteria of evaluation were objective standard. The results of evaluation from the real life were compared with the set objective standard. The criteria of the evaluation of the supervision program of science learning in secondary school in Gorontalo city were presented on the following Table 1.

Table 1: Criteria of the success of supervision program evaluation of science in secondary school in Gorontalo

\begin{tabular}{|c|c|c|}
\hline Evaluation step & Indicator & Criteria of the success \\
\hline $\begin{array}{l}\text { Context: } \\
\text { Policy support }\end{array}$ & $\begin{array}{l}\text { 1. Supervision } \\
\text { policy of science } \\
\text { learning } \\
\text { 2. Comprehension } \\
\text { of the policy } \\
\text { maker }\end{array}$ & $\begin{array}{l}\text { 1. The presence of regulation, decision and } \\
\text { publication of the chief of the department } \\
\text { related with the supervision. } \\
\text { 2. Comprehension on the concept, theory, } \\
\text { principle, and function of the supervision, } \\
\text { which was then implemented on the } \\
\text { implementation of monitoring and } \\
\text { evaluation (once in three months } \\
\text { minimum). }\end{array}$ \\
\hline \multirow[t]{4}{*}{$\begin{array}{l}\text { Input : } \\
\text { Resources (science } \\
\text { teacher, supervisor, } \\
\text { headmaster, facility } \\
\text { and infrastructure) }\end{array}$} & $\begin{array}{l}\text { 1. Comprehension } \\
\text { of the science } \\
\text { teacher about the } \\
\text { concept of } \\
\text { supervision of } \\
\text { science learning }\end{array}$ & $\begin{array}{l}\text { 1. The science teacher who comprehended the } \\
\text { concept, theory, principle and function of } \\
\text { the supervision tried to ask the help from } \\
\text { the supervisor to solve the problem in the } \\
\text { learning process in the class (once in two } \\
\text { weeks minimum). }\end{array}$ \\
\hline & $\begin{array}{l}\text { 2. Comprehension } \\
\text { of supervisor } \\
\text { about the } \\
\text { concept of } \\
\text { supervision of } \\
\text { science learning }\end{array}$ & $\begin{array}{l}\text { 2. The supervisor who had the concept, } \\
\text { theory, principle and function of the } \\
\text { supervision helped the science teacher in } \\
\text { solving the problem in the learning process } \\
\text { in the class (once in two weeks minimum). }\end{array}$ \\
\hline & $\begin{array}{l}\text { 3. Comprehension } \\
\text { of headmaster } \\
\text { about the } \\
\text { concept of } \\
\text { supervision of } \\
\text { science learning }\end{array}$ & $\begin{array}{l}\text { 3. The headmaster who had the concept, } \\
\text { theory, principle and function of the } \\
\text { supervision helped the science teacher in } \\
\text { solving the problem in the learning process } \\
\text { in the class (once in two weeks minimum). }\end{array}$ \\
\hline & $\begin{array}{l}\text { 4. Characteristic of } \\
\text { the supervisor of } \\
\text { science learning }\end{array}$ & $\begin{array}{l}\text { 4. Supervisor had the academic qualification } \\
\text { of bachelor degree in the cluster of science } \\
\text { 5. Supervisor had the certificate of }\end{array}$ \\
\hline
\end{tabular}




\section{Process:}

Implementation of supervision of science learning
International Journal of Education

ISSN 1948-5476

2013, Vol. 5, No. 4 in Gorontalo city

5. Characteristic of science teacher

6. Facility and infrastructure
1. Implementation of supervision of science learning in secondary school in Gorontalo city by the supervisor supervision/teaching

6. The teacher had the academic qualification of bachelor degree in the cluster of science

7. The teacher had the certificate of teaching

8. Each science in secondary school had one science laboratory equipped with table and chair that sufficient enough for 36 students and one set of tool from the laboratory work.

9. Each class had no more than 36 students.

10. Each student had 1 science book.

11. Each teacher had his own desk.

1. Implementation of supervision of science learning in secondary school learning in Gorontalo city by the supervisor included:

a) Visitation to the class twice in a month to do the supervision (3 hours).

b) Private meeting twice in a month.

c) Teacher meeting once in a month.

d) Inter-class visitation once in a semester.

e) Visitation to the school once in 6 months.

f) Implementation of research once in a semester;

g) Preparation of scientific journal once in a semester.

2. Implementation

2. Implementation of supervision of science of supervision of science learning in secondary school in Gorontalo city by the headmaster learning in secondary school in Gorontalo city by the headmaster included:

a) Visitation to the class twice in a month to do the supervision (3 hours).

b) Private meeting twice in a month.

c) Teacher meeting once in a month.

d) Inter-class visitation once in a semester.

e) Visitation to the school once in 6 months.

f) Implementation of research once in a semester;

g) Preparation of scientific journal once in a semester.

3. Perception of the 3. Perception of the science teacher about science teacher supervision of science learning in about secondary school in Gorontalo city 
supervision of

science learning

in secondary

school in

Gorontalo city included :

a) Visitation to the class twice in a month to do the supervision (3 hours).

b) Private meeting twice in a month.

c) Teacher meeting once in a month.

d) Inter-class visitation once in a semester.

e) Visitation to the school once in 6 months.

f) Implementation of research once in a semester;

g) Preparation of scientific journal once in a semester.
4. The effort of the supervisor to improve the competences

5. The effort of the headmaster to improve the competences

4. The supervisor was active on the seminar, training and workshop (once in 6 month minimum).

5. The supervisor was active on the association of supervisor (once in 6 month minimum).

6. The supervisor was active on the seminar, training and workshop (once in 6 month minimum).

7. The supervisor was active on the association of headmaster (once in 6 month minimum).

$75 \%$ of the teacher conducted the science

Product :

Performance of learning with the performance value $>80$

Teacher science teacher in secondary school performance

in Gorontalo city

\section{Method}

According to the background and the focus of the problems, thus, this research was aimed to (1) obtain information related to the support of policies toward the supervision program of science learning in secondary school in Gorontalo city, (2) obtain information related to the resources of the supervision program; (3) obtain information related to the implementation of the supervision program; and (4) obtain the information related to the performances of science teacher in secondary school in Gorontalo cities.

This research was conducted in the National Department of Education and secondary school in Gorontalo city for 9 months (January-September 2011). The program evaluation was carried out using descriptive method of Context, Input, Process and Product (CIPP).

The techniques employed in this research were interview, observation and documentation. Interview was used to obtain information about the policy, comprehension of the policy 
maker, natural science, supervisor, headmaster on the concept, implementation of supervision in order to enhance the competencies. Documentation was performed to obtain the data on the characteristic of science teacher and supervisor of science in secondary school in Gorontalo city, facilities and infrastructures as well as the performance of the teacher. Observation was carried out to obtain the data related to the implementation of supervision of science in secondary school in Gorontalo city.

The analysis of data in this study was conducted by using the qualitative descriptive method. Besides, the qualitative data were analyzed using thematic analysis.

\section{Results}

\subsection{Evaluation Contexts}

The evaluation of contexts consist of supervision policy and the understanding of policy makers which is presented as follow:

\subsubsection{Supervision Policy}

The rules of implementation of supervision was regulated by National Constitution of Republic Indonesia Number 20, 2003 about national educational system, Government Regulation Number 19, 2005 about SNP, Ministry Regulation Number 12, 2007 about standard of supervision of school, Ministry Regulation Number 13, 2007 about standard of headmaster of school and Ministry Regulation No 15, 2010 about MSS of fundamental education.

\subsubsection{The Understanding of Policy Makers}

Implementation of supervision was based on the current law and regulation. In addition, it was also formulated several policies of the chief of department, such as Consultative Forum of School Supervisor (Musyawarah Kerja Pengawas Sekolah, MKPS), Consultative Forum of Teacher (Forum Musyawarah Guru Mata Pelajaran, MGMP), Association of Similar Teacher (Asosiasi Guru Sejenis, IGS) and performance contract to strengthen and support the implementation of law and regulation on the supervision of science learning. The performance assessment of the implementation of supervision was conducted once a year by meeting among the school supervisors, headmasters and the policy makers. The policy maker understood of the implementation of the science supervision was still restricted on the regulation. They were not in the effort to improve the quality of supervisor, headmaster and the teacher, yet.

\subsection{Evaluation Inputs}

The indicators of input evaluation were comprehension of supervisor, headmaster, and science teacher on the supervision concept, characteristic of supervisor and science teacher, and facility and infrastructure which is presented as follow: 


\subsubsection{Comprehension of Supervisor on the Supervision Concept}

Implementation was conducted using the techniques of administration, process and clinic. The learning supervision utilized the academic supervision technique, i.e. the visitation to the class and feedback. Supervision to the teacher was conducted individually or in group and based on the problem. The right method of the implementation of supervision was by using the approaches of humanistic, competency, clinic and class visit. The science learning was contextually conducted using active and fun learning with emphasizing on the cognitive, affective and psychomotor aspects. The learning was aimed to study the natural phenomena, and to increase the skill of the learning, develop the curiosity, increase the confidence to the almighty God. The assessment of the learning was continuously carried out based on the achievement of the indicators and focus on the learning activity including the introduction, core activity and closing. The action research was the solution to improve the science learning in class which was based on the problem in the class. Based on the research data, the supervisor has understood the concept of the supervision implementation at the technical level, while at the levels of concept and theory, the supervisor has not fully understood the nature of supervision as the professional efforts to help the teacher to be professional teacher.

\subsubsection{Comprehension of Headmaster on the Supervision Concept}

Implementation was based on Ministry of National Education Regulation Number 41, 2007 about the standard of process and the publication of department. The concept of learning was conducted based on the integrated science concept. The nature of the science learning was aimed to understand the nature and the God, which should be applicative and may build the character of the student. Coordination system of the supervision implementation in the class was conducted by forming the supervision team in school which always made coordination with the headmaster and the supervisor. The monitoring of the implementation of the learning was directly done by the headmaster, vice headmaster and the chief of IGS. The utilization of information technology to support the learning process should be optimized. However, it has not been optimally conducted yet. The headmaster should make the way to motivate the teacher in reflecting the results through the supervision and performance assessment. Based on the previous data, the headmaster has only understood the concept of the supervision implementation at the technical level. On the levels of concept and theory, the headmaster has not fully understood the concept, thus the nature of supervision could not be observed yet.

\subsubsection{Comprehension of Teacher on the Supervision Concept}

Implementation could be conducted by the workshop through the IGS. Then, the program was continued by supervising the teacher from the preparation of learning, analysis of the learning concept and the evaluation. The supervisor routinely came to supervise the teacher and do the direct monitoring in the learning process in the class. In the term of the comprehension of the teacher on the science learning concept, the concept was contextually carried out. The teacher explained the principle of the learning in order to understand the nature and be aware of the power of the God and foster the love to the God. The supervision of teacher in planning the science learning included the preparation of the learning devices, material, learning model, evaluation, utilization of media. In addition, eight basic teaching 
skills should be enhanced. The frequency of supervision conducted by the supervisor might be varied. The teacher was also participated on MGMP or Teacher Work Group (KKGKelompok Kerja Guru). According to the previous explanation, the teacher principally comprehended the concept of supervision based on the implementation of supervision conducted by the supervisor and headmaster.

\subsubsection{Characteristic of Supervisor}

The characteristic of the supervisor consist of number of science supervisor was 3 . There were 2 persons who had the bachelor degree in physic with the background of master of Population and Enviromental Education (PKLH- Pendidikan Kependudukan dan Lingkungan Hidup) and educational management. There was also 1 person with bachelor degree in chemistry with the background of master degree of PKLH. All of them have the rank of IVa. The supervisors were divided into the monitoring area which included secondary schools and senior high schools. Based on the data, all of the supervisors in Gorontalo were productive and had the potential to develop.

\subsubsection{Characteristic of the Teacher}

The number of science teacher in Gorontalo city was 94 persons, including 32 persons with bachelor degree on biology, 35 persons with bachelor degree on physic, 21 persons with bachelor degree on education of science, 2 persons with master degree on educational management, 3 persons with master degree on biology and 1 person with D3 degree on biology. The number of teacher with the work period under 10 years, above 10 years and above 20 years was 30, 44 and 10 persons, respectively. The number of teacher with the rank of III and IV was 47 and 45 persons, respectively. There were 81 teachers which have been certified, while there were 13 uncertified teachers. Those who have not been certified, have not had enough work experiences. Therefore, the character of teacher was possible to develop through the supervision.

\subsubsection{Facility and Infrastructure}

The facility and infrastructure of the learning could be viewed from several aspects, such as the number of student in a class, table and chair in the class, the teacher and headmaster rooms, laboratory and the tools for the laboratory work, the number of science book. In general, the number of student was 36 which were the same with the number of table and chair. There were also the teacher and headmaster rooms, laboratory and devices which already meet the minimum standard. The number of science book also met the requirement. Based on the data, it could be said that the facility and infrastructure may increase the teacher performance.

\subsection{Evaluation Process}

The indicators of the evaluation of process were the implementation of the supervision of science by the supervisor and headmaster, the perception of the teacher on the implementation of supervision, the effort of supervisor and headmaster to improve the competence which is presented as follow: 


\subsubsection{Implementation of the Supervision of Science by the Supervisor}

The implementation of class visit by the supervisor was conducted twice in a semester for each teacher. The supervision process included the initial supervision in a group and individual supervision. The private meeting was conducted for 3 times. It could be happened if the devices prepared by the teacher have not met the requirement yet. The supervisor supervised the teacher in choosing and employing the method/strategy of the learning based on the characteristic of material, the teacher readiness, and the facility. The supervisor also supervised the teacher to prepare lesson plan from the introduction until the closing by learning and checking the deficiency. Therefore, the teacher knew the deficiency of lesson plan. The guiding of the learning media was focused on the teacher who did not have any skill in employing the media. It was carried out by conducting the training of science devices. Similarly, the training of information technology was focused on the teacher with no skill on the technology. The participation of supervisor in the teacher meeting could be conducted in order to discuss the competence of the teacher or the evaluation of supervision or the learning process. Based on the data, the supervisor has only done the supervision based on the frequency regulated by the department of education (2 or 3 times in a semester). Thus, the continuous supervision has not been observed yet (2 times in a month with the duration of 3 hours for each meeting).

\subsubsection{Implementation of the Supervision of Science by the Headmaster}

The class visit was conducted by the headmaster twice in a semester through both school internal and supervision with the supervisor. The private meeting related to the supervision was scheduled to be 2 times in a semester (at the beginning of learning and at the integrated supervision). The teacher meeting was conducted for three times in a semester (at the beginning, at the middle and at the end of semester). The implementation of the school visit has been scheduled in MGMP. The headmaster only obtained the information of the school visit by the teacher. According to the headmaster, the inter-class visit has been conducted. It was done to guide the teacher to fix the learning quality in the class. The other headmaster has not conducted with the teacher. Also, KKG science was programmed in the activity of MGMP. The publication of innovative results in the scientific paper has not been carried out. There was also the publication, but not optimal. The assessment of the teacher performance was based on the instrument on the school supervisor. Based on the data, the headmaster has conducted the supervision only by observing the learning process in the class. However, the headmaster has not done the continuous and sustainable supervision based on the minimum service standard (twice in a month and 3 hours for each meeting).

\subsubsection{The Perception of the Teacher on the Implementation of Supervision}

The perception of the teacher on the implementation of supervision is the supervisor visited to guide the teacher and do the monitoring in the learning process. It was stated that the class visit was carried out by the supervisor 1, 2 or 3 times in a semester. The private meeting was done by the supervisor 1 to 2 times in a semester. Some teacher said that the group meeting was conducted instead of the private one. The teacher stated that the learning concept was conducted contextually. The principle of the learning was to understand the natural 
phenomena and be aware of the power of the God. The supervision was conducted through the workshop initiated from the school supervision through the IGS. It was consisted of the analysis of the learning concept, the preparation of the lesson plan based on the syllabus, the determination the indicator based on the standard of the competency, the choosing the learning method, the development of learning media and the utilization of ICT on the learning. The supervisor introduced the active, creative, efficient and fun learning. It also observed the learning process in class from the beginning until the end of learning. The process was continued by the reflection. The supervision on the utilization of information technology was performed, such as to prepare the power point, use the LCD, download the learning material. All of the teachers stated that the supervision on the preparation of the learning material has been conducted, while the supervision on the information technology has not been much done. Among 9 respondents, 3 respondents stated that there was no effort to publish the innovative research on science on the scientific paper. Based on the previous explanation, the perception of the teacher on the implementation of supervision has not been optimally conducted by the supervisor. Therefore, the skill of the teacher should be optimized.

\subsubsection{The Effort of Supervisor to Enhance the Competence}

The supervisor was directly involved as the participant of the training, seminar and workshop, conducted the coordination with the member of MKPS, used the information technology to find the information related to the supervision activities. In addition the association of supervisor in the level of city has not been formed and the coordination with Education Quality Assurance Institution (LPMP, Lembaga Penjaminan Mutu Pendidikan) was individually conducted, particularly related to the quality of the supervision. The information was in the form of the mutual work activity. Based on the data, the supervisor has done some efforts to enhance the competence.

\subsubsection{The Effort of Headmaster to Enhance the Competence}

The headmaster has done some effort to achieve the 8 competition standard of the headmaster and has joined the training, seminar and workshop to develop the competence. The other efforts were by comprehending the preparation of the school planning, optimizing the school resources, developing of the school to be the effective learning organization, developing the condusive and innovative learning, managing the teacher and staff, managing the facility and infrastructure of school, managing the relationship between the school and the society in order to find the learning support, developing the capacity of the student, developing the curriculum and learning process based on the aims of the national education. Based on the previous explanation, the headmaster has done several efforts to improve the competence as explained on Ministry Regulation Number 13, 2007 about the standard of headmaster.

\subsection{Evaluation Products}

The teacher performance was the ability of the teacher in preparing `the learning device and conducting the learning process in the class. Based on the data, the number of teacher with excellent (score $>90)$, good (90 > score $>75)$ and enough $(74>$ score $>56$ ) was $10(16 \%)$, 
$26(43 \%)$ and $3(5 \%)$ persons, respectively. Some teachers did not have a will to be supervised. On the other word, the principle of participation was not optimal yet. Besides, the research has conducted the observation on the learning process which was done by the teacher. The teacher has conducted the initial activities such as preparing the student, explaining the basic competence and the aim. The main activities included the exploration, elaboration and confirmation. It was showed that in the observation process, some of the teacher has employed the learning media and used the cooperative learning model. However, the learning was dominated by the teacher and the teacher was still passive.

\section{Discussion}

In this section, the results of evaluation program of the learning supervision consisted of 4 steps of evaluations: (1) context, (2) input, (3) process and (4) product.

The implementation of the supervision has been conducted based on National Constitution of National Education System Number 20, 2003, Government Regulation Number 19, 2005 about SNP, Ministry Regulation Number 12, 2007 about the standard of school / madrasah supervision standard, Ministry Regulation Number 15, 2010 about the MSS of fundamental education. However, some aspects were not in line with the previous policies.

Some policies of Department of Education supported the implementation of the supervision including the partition of the target area, to activate MKPS, MKKS (Musyawah Kerja Kepala Sekolah- Consultative forum for headmaster), MGMP and IGS, to prepare the work contract between the chief of department and supervisor, supervisor and headmaster, headmaster and teacher. The indicators were the minimal completeness criteria (Kriteria Ketuntasan Minimal, $\mathrm{KKM}$ ), the teacher mutation, integrated supervision, workshop, seminar and training. The policies were made to improve the competences of supervisor, headmaster and teacher and to improve the achievement of the education.

The policy of the government which was related to the implementation of the learning supervision should be optimized, particularly on the level of implementation. The policy maker understood the implementation was restricted to the regulation. The decision of the policy has not in the enhancement of the qualities of the supervisor, headmaster and teacher.

Based on the previous explanation, the decision maker should understand the implementation of learning supervision. The supervision was the professional service and should be continuously carried out.

The comprehension of the teacher on the supervision concept will help the supervisor and headmaster to achieve the supervision. Therefore, the supervisor should give the understanding to the teacher about the natural learning supervision. This would be occurred if there was the harmonic cooperation between the teacher and the supervisor. The teacher principally understood the supervision concept based on the experience and the implementation of the supervision by the headmaster and supervisor. The comprehension of the teacher on the supervision concept was the reflection of the supervision. 
In the comprehension of the teacher on the supervision concept, supervisor not only trained the teacher through the workshop, trained the preparation of the learning, trained the concept of learning and did the monitoring the learning process, but also the supervisor gave the professional help to the teacher. The implementation of the supervision was continuously and sustainably performed with the basis of the interest of both parties.

The comprehension of the supervision concept was restricted to do the visit to the school, observed the teacher to prepare the teaching, discussion or the feedback. The techniques employed were the supervisions of administration, process and clinic.

The understanding of the headmaster on the learning concept has met the expected objectives. It was contextually conducted with the main aim to understand the principle of the nature and the God. However, the headmaster should understand that the learning should be initiated by observing the natural phenomena and producing the products such as the natural knowledge, fact and theory.

The supervisor had the minimum education of master of education and the relevant background of bachelor degree, had the rank of IVa, had the productive age under 50 years. These have already met the regulation stated on the section of context which explained the policy support. Based on the potency of the supervisor, it is possible to improve the qualification to be the professional one.

The number of student in a class in Gorontalo was 28-35 persons and has met the regulation of the Ministry of National Education Regulation Number 15, 2010 about the MSS of the fundamental education. However, Ministry of National Education Regulation Number 19, 2005 about the SNP has not been fulfilled. It was stated in MSS that the maximum student on the class was 36 persons, while in MSS was 32 persons. These gave the significant effect on the learning process, thus the learning could be designed in order to motivate the student to be active, creative and happy to learn the sciences.

The secondary school in Gorontalo had the main requirement of laboratory to conduct the qualified learning process. The laboratory supported the transfer of information and knowledge to the student.

Based on the previous explanation, the supervision concept should be understood by the teacher, supervisor and headmaster as the professional help which continuously and sustainably performed in order to create the way of thinking of student. Besides, the teacher, supervisor and headmaster should develop their capacities as the educator and leader who had the responsibilities on the development of the high quality human resources of the student.

The implementation of the supervision by the supervisor and the headmaster will make the view and the behavior of the teacher in the term of the learning supervision. Therefore, the teacher considered that the learning supervision was the activities conducted by the supervisor, headmaster to check lesson plan, observe the learning process and give the feedback after the learning process. The teacher has not obtained the description of lesson plan, yet. The teacher only obtained the recommendation and suggestion on the feedback but 
not on the description on the implementation of learning, particularly on the utilization of media, method, learning model and the assessment.

The teacher felt that the development of competences related to the Action Research (PTK, Penelitian Tindakan Kelas) and the writing on the journal were difficult to conduct by the teacher. This was probably due to the lack of experiences, such as the writing of thesis. Some of the teachers did the research only with the main aim to increase the rank.

The effort of supervisor and headmaster to improve their competences in conducting the learning supervision was conducted through the education, training, seminar, workshop as well as doing the coordination between the supervisor and headmaster in the term of MKPS and MKKS. Besides, the qualified supervisor should do the PTK. This should be the basis to improve the competences to guide the teacher.

Based on the previous explanation, the implantation of the learning supervision has not been optimally conducted yet by the supervisor and the headmaster since the lack of supervisor in Gorontalo and there was no monitoring on the supervisor. Therefore, the number of science supervisor should be added and the evaluation of the structural organization on the department of education should be done. In addition, both supervisor and headmaster should develop themselves through the literature study, should do the activities of education and the training, should invite the speaker from Teaching Institution (LPTK, Lembaga Pendidikan Tenaga Kependidikan) or LPMP, should follow the association of supervisor and headmaster either in the levels of national or local.

The performance of the science teacher was the ability and the effort of teacher to do optimally the learning task in planning the learning program, implementation of the learning activity and evaluation of learning results. The achieved teacher performance should be based on the standard of the professional competency during conducting the duty of teacher in school. Therefore, the attention to the teacher performance by the supervisor and headmaster should be increased. The increase on the demand of society should be also considered as it was related to the quality of education. This implied to the increase of the quality of teacher performance.

The performance of the teacher really determined the perception of the student for the subject of sciences. This was described on the results of National Examination in Gorontalo city. There were some basic competencies (Kompetensi Dasar, KD) with the perception under 60\% even $15.08 \%$. The attention should be given by the supervisor by designing the learning and employing the available potency with the orientation of active, creative, effective and funny learning. Besides, the supervisor and headmaster were advised to do the task based on the guidelines in order to improve the performances.

Based on the previous explanation, the government policies related to the supervision program have given the clear description about the principle of the implementation of the supervision. However, the comprehension of the policy maker on the department of education on the level of city should be optimized. In addition, the chief of department of education should understand the problems related to the learning supervision in the school. 
The comprehension of the policy maker on the principle of the supervision would be the need of the supervisor to implement the supervision program, particularly in recruitment of human resources and providing the facility and infrastructure.

The human resources of supervisor, headmaster and the teacher which supported by the complete facility and infrastructure will give the contribution on the implementation on supervision in Gorontalo. The implementation will only succeed if the human resources understand the principle of the supervision. The success implementation of the supervision could be shown by the increase of the teacher performance on the learning process.

\section{Conclusion}

The policy support of the science supervision program in Gorontalo city was based on National Constitution of Republic Indonesia Number 20, 2003 about the national education system, Ministry Regulation Number 19, 2005 about the standard of national education, Ministry Regulation Number 12, 2007 about the standard of the supervisor of the school, Ministry Regulation Number 13, 2007, about the standard of the headmaster/madrasah, Ministry Regulation Number 15, 2010 about the minimum service system of fundamental education. The implementation of the policy of department of education in Gorontalo on the supervision program was conducted by dividing the work area, activating the MKKS, MKPS, Kelompok Kerja Pengawas Sekolah (KKPS-work group of school's supervisor), Kelompok Kerja Kepala Sekolah (KKKS- work group of headmaster), MGMP, and IGS, preparing the work contract between the chief of the department and the supervisor, supervisor and the headmaster, the headmaster and the teacher, the integrated supervision, workshop, seminar and training. Besides, the comprehension of the policy maker on the implementation was still restricted on the understanding of the regulation and the implementation has not been optimally carried out yet.

The resources of the supervision included the teacher, headmaster, supervisor and the infrastructure as well as the facility. The teacher understood the concept of the supervision based on the experiences and the implementation of the supervision conducted by the supervisor and the headmaster. Then, the understanding of the headmaster and the supervisor on the concept of supervision was restricted on the school and class visits in order to see the lesson plan and the teacher and gave the feedback. In the level of concept and theory, they have not fully comprehended the principle of supervision as the professional efforts to help the teacher to be the professional teacher. The characteristic of the supervisor and teacher has met the standard of national education and might be developed. The facility and infrastructure support the supervision have met the minimal standard of fundamental education.

The implementation of the supervision by the supervision and headmaster has been conducted. However the frequency has not met the regulated requirement of the minimal standard of fundamental education (twice in a month with 3 hours for each meeting). Some of teachers have not joined the scientific activities such as meeting of MGMP, seminar, training, workshop, and done the research of class and written an article to the scientific journal. The 
perception of the teacher of the implementation of supervision was that the supervision was conducted with the main aim to enhance the quality and to find the solution of the problems in the class. However, there were some teachers who were afraid to be supervised. The effort of supervisor and headmaster in increasing their competencies could be done through education, training, seminar, workshop, conducting the coordination between the supervisor and headmaster on MKPS and MKKS. The utilization of information technology to find the information has not been optimally done in the supervision.

The performance of the teacher could be classified into excellent (16\%), good (43\%) and enough (5\%). The rest (36\%) teacher had no willingness to be supervised. On the other word, the principle of the participation and commitment among the supervisor, headmaster and teacher has not optimally conducted on the supervision program in Gorontalo city.

\section{Recommendation}

The government policy related to the implementation of the supervision should be optimized particularly on the level of implementation. The results of supervision should be evaluated and analyzed. The policy maker should understand the concept of implementation particularly about the professional help to the teacher and it should be continuously and sustainably conducted.

The concept of learning supervision should be considered by the teacher, supervisor and headmaster as the professional help to the teacher to improve the learning quality in the class and the quality as well as the way of thinking of the students. The number of the supervisor was not enough and there was no supervisor with the background of bachelor degree on natural science. Therefore, the number of supervisor with the background of science should be increased. The number of class and laboratory device should be added.

The implementation of supervision in Gorontalo by the headmaster and the supervisor should be carried out through the scientific activities, such as MGMP, seminar, training, workshop, class research and journal writing. These activity should be continuously conducted and involve the teacher. Therefore, both the headmaster and supervision should enhance their competences by joining the training, intensifying the activities of MKPS and MKKS and being active on the association of supervisor, performing the researches of school and class actions, writing the scientific journal, as well as employing the internet and e-learning.

In order to improve the performance of teacher, thus supervision should be continuously and sustainably conducted with the assistance of supervisor and headmaster. The policy maker should give the reward to the supervisor, headmaster and teacher with the good achievement. Those with less achievement should be assisted to improve the competencies.

\section{Acknowledgement}

Thanks for Prof. Djaali Jakarta State University and Prof. Yoseph Paramata Gorontalo State University, supervisors, teachers, principals, and heads of Gorontalo city education office. 


\section{References}

A.M, M. (2005). Evaluation On Dual System Of Education Program An Evaluation Research Based on Stake's Countenance Model on Dual System Of Education Program at a SMK in South Sulawesi (Doctoral disertasion). Retrieved from http://www.damandiri.or.id/file/muliatyunjbab.pdf

Aderusliana. (2009). Mencari Supervisor IPA di Indonesia (Looking for IPA supervisor in Indonesia). $\quad$ Retrieved from http://www.psb-psma.org/content/blog/mencari-supervisor-ipa-di-indonesia

Batavia, V. F. (2008). Program Evaluasi Metode CIPP. Retrieved from http://fuddin. wordpress. com/ 2008/07/02/ teorievaluasidengancipp/

Johnson, B. (2011). Evaluation Model. Retrieved from http://www.south alabama.edu/coe/bset/johnson/6601ectures/Lect2.doc

Masaong, A.K. (2010). Supervisi Pendidikan Untuk Pendidikan yang lebih Baik (Education supervision for a better education ). Bandung: MQS Publishing.

McLemore, A. (2011). The CIPP Model. Retrieved from http://birdopassage.blog.com/2011/08/28/thecippmodel/

Paramata, Y. (2001). Pengembangan Model Sosialisasi Inovasi dan Supervisi Pembelajaran Ilmu Pengetahuan Alam. (Unpublished doctoral disertasion). Universitas Pendidikan Indonesia. Bandung

Peraturan Menteri Pendidikan Nasioanl Nomor 12. (2007). Standar Pengawas Sekolah/Madrasah. Jakarta: Kemendikbud RI.

Peraturan Menteri Pendidikan Nasioanl Nomor 13. (2007). Standar Kepala Sekolah/Madrasah. Jakarta: Kemendikbud RI.

Peraturan Menteri Pendidikan Nasional Nomor 15. (2007). Sistem Pelayanan Minimal Pendidikan Dasar. Jakarta: Kemendikbud RI.

Peraturan Menteri Pendidikan Nasional Nomor 41. (2007). Standar Proses. Jakarta: Kemendikbud RI.

Peraturan Pemerintah Republik Indonesia Nomor 19. (2005). Standar Nasional Pendidikan. Jakarta.

Pratama, D. (2011). Model Evaluasi CIPP (Context, Input, Process, Product). Retrieved from http://dinarpratama.wordpress.com/2010/11/20/modelevaluasicippcontextinputprocesspr oduct/

Roswati. (2008). Evaluasi Program/proyek (Pengertian, fungsi, jenis dan format usulan). Jurnal Pendidikan Penabur, No.11 Tahun ke7. Retrieved from http://www.bpkpenabur.or.id/files/Hal.\%2064-71\%20Evaluasi\%20Program.pdf. 


\section{Macrothink}

International Journal of Education ISSN 1948-5476 2013, Vol. 5, No. 4

Sergiovanni, T.J., \& Robert, J.S. (2011) Supervision: A Redefinition. Retrieved from http://www.amazon.com/Supervision-A-Redefinition-Thomas-Sergiovanni/dp/00731312 61

Undang-Undang Republik Indonesia Nomor 20. (2003). Sistem Pendidikan Nasional. Jakarta.

\section{Copyright Disclaimer}

Copyright reserved by the author(s).

This article is an open-access article distributed under the terms and conditions of the Creative Commons Attribution license (http://creativecommons.org/licenses/by/3.0/). 